\title{
Study of Stress and Coping Strategies in Competitive Entrance Exams Aspirants Attending Medical and Engineering Coaching Institutes in Delhi
}

\author{
Vanita Mann \\ Research Scholar, Amity Institute of Education, Amity University, Uttar Pradesh \\ Dr. G.N. Tiwari \\ Associate professor, Amity Institute of Education, Amity University, Uttar Pradesh
}

Prof. Loknath Mishra

Professor, Mizoram University, Aizwsal, Mizoram

\begin{abstract}
Aims: To study the sources of stress of the medical and engineering competitive entrance exam aspirants attending coaching institutes in Delhi. Second, to study stress coping strategies used by the medical and engineering competitive entrance exams aspirants attending coaching institutes in Delhi. Third, to suggest some more stress coping strategies to parents and teachers. Methods: The study was descriptive in nature and cross-sectional study design was used. The study was conducted in August 2019.The population of the study consisted of the students preparing for medical and engineering competitive entrance exams who attend full time coaching institutes in Delhi and also attend their school. The sample of the study was 400 students, 200 each from medical and engineering coaching institutes in Delhi. A self -designed questionnaire was used to collect data. The questionnaire consisted of two sections, the first section consisted of questions related to sources of stress and the second section comprised of questions related to stress coping strategies practice by the medical and engineering competitive entrance exam aspirants attending coaching institutes in Delhi .The questions were open ended based on 4 point Likert Scale.The questionnaire was administered to students and they were asked to fill the questionnaire. A total of 380 students out of 400 completed the questionnaire. The
\end{abstract}

data was analysed using descriptive statistics. Frequency and Percentage analysis of each item of the questionnaire was done. Mean score and standard deviation of each item of the questionnaire was compiled. Findings: The study findings indicated that majority of the students reported academic (48\%) and parental $(39 \%)$ stressors as sources of stress. However personal $(8 \%)$ and environmental stressors (5\%) also contributed as the sources of stress to the medical and engineering competitive entrance exams aspirants attending coaching institutes in Delhi. The aspirants cope stress by using strategies such as practising yoga, listening music, surfing the internet, talking to like-minded people, playing outdoor games, communicating with parents and doing meditation. Some other coping strategies suggested by the researcher are practice visualization, taking calming breathe, practice progressive muscle relaxation, get organised, trying self- hypnosis. Novelty: The study investigates stress and coping strategies in competitive entrance exams aspirants attending medical and engineering coaching institutes in Delhi . It throws light on adolescent's stress and the coping strategies used by these adolescents; hence the study contributes in providing remedies to handle stress by the parents, students and teachers. The study also provides basis to researchers for further in depth study of stress faced by students preparing for other 
competitive entrance exams and also to those students who do not attend coaching institutes and still aspires to prepare for competitive exams.

Keywords: Stress; Competitive Exams Aspirants; Medical students; Engineering students; Coaching Institutes ; Stress coping strategies.

Introduction: Stress is defined as body's nonspecific reaction to demands made on it. It is a process by which we perceive and cope with environmental threats and challenges. Hence, stress is defined as emotional and behavioural changes caused by stressors. Growing competition and pressure of performance is turning student into victims of stress. This is true with those appearing for competitive exams. The student's performance is evaluated through examinations. This has increased academic pressure on student's preparing for competitive exams. Academic stress has become a prevalent problem across countries, cultures, and ethnic groups. Parental expectations and fear of failure in exams are the two significant factors responsible for academic success (1). Academic stress is a major concern for secondary and tertiary students. The ongoing stress related to education has demonstrated negative impact on students learning capacity, academic performance , education and employment attainment ,sleep quality and quantity, physical health ,mental health and substance use outcomes(2). Academic stress is positively related with parental pressure and psychiatric problem. Examination related anxiety is also observed to be related to psychiatric problem (3). Recent findings of UNESCO reveal that students preparing for competitive exams are undergoing severe stress, which results in anxiety disorders and mental stress. Recent statistics reveal that suicide rates among students preparing for entrance examinations after plus 2 and professional colleges are on the rise. According to reports of National Crime Records Bureau (NCRB), in 2019, at least one student died by suicide every hour in India. The year recorded the highest number of student suicides, 10,335, in the past 25 years for which data is available. Between January 1,1995 and December 31,2019, India lost more than 1.7 lakh students to suicide. In 2019 , at least one student died by suicide every hour in India, 28 such suicides reported everyday. The NCRB data shows that 10,159 students died by suicide in 2018 , an increase from 9,905 in 2017 , and 9,478 in 2016. Between 1999 and 2003, 27,990 students ended their lives : 28,913 between 2004 and 2008 and 36,913 between 2009 and 2013. The period 20142018 saw a $26 \%$ jump from the preceding 5 year period to 46,55 (16). The statistics for student suicides 2020 by the NCRB is not available till on NCRB portal. Failure in examinations accounted for $2 \%$ student suicides. With one student committing suicide every hour, inability of coping with failure and fear of letting their family down makes students resort to such desperate measures. Forced career choices and the inability of children to speak up about the pressure, especially with their parents is also a major contributor to the student suicide numbers. According to Md. Sanjeer Alam, faculty at the Centre for the Study of Developing Societies , New Delhi, said,' 'A student commits suicide when he doesn't get emotional support at the time of crisis. This might happen when individual expectations are too high. Parental and peer pressure also have an adverse effect"9(The Hindu). United Nations Annual Global Education Monitoring Report 2016 -17 by UNESCO reveals that private tutions increase student's academic burden and stress. According to a recent study published by the National Institute of Mental Health and Neuro- Sciences, one in every five teenagers in India faces mental illness. According to the World Health Organisations (WHO), mental health problems in India is equivalent to 2,443 DALYs (Disability Adjusted Life Years) per 100,000 population(5). Adolescents who have joined coaching institutes for admission to professional courses experience self- inflicted stress, parent inflicted and peer inflicted stress . The highly competitive education and learning processes are affecting adolescent's mental state (6).Kota, primarily known as a coaching centre hub (Medical and Engineering) has seen a series of students deaths every year. As per the data available from the district administration , 58 students ended their lives in Kota between 2013 and 2017. Results of a study reveals that among 400 participants, $19.5 \%$ were found to be in a mild depression, $20.3 \%$ in moderate depression and 
$8.8 \%$ were found to be severely depressed. Overall depression on management involves complete lifestyle change that requires a range of strategies and techniques. They include good eating habits, proper exercise, good family and social life, mood management and relaxation techniques (7). Park and Adler reported that effective and appropriate coping strategies may buffer the impact of newly encountered stressful situations on mental and physical health. Therefore, using coping strategies effectively and appropriately will help the students in improving their stress level (8). Few studies have been done on stress and stress coping strategies of the medical and engineering competitive entrance exams. Therefore, this topic study of stress and coping strategies in competitive entrance exams aspirants attending medical and engineering coaching institutes in Delhi was decided for study by the researcher.

\section{Year Wise Comparison of Students Suicides}

According to the data provided by the National Crime Records Bureau

\begin{tabular}{|l|l|}
\hline Year & Student Suicides \\
\hline 2011 & 7,696 \\
\hline 2012 & 6,654 \\
\hline 2013 & 8,423 \\
\hline 2014 & 8,068 \\
\hline 2015 & 8,934 \\
\hline 2016 & 9,478 \\
\hline 2017 & 9,905 \\
\hline 2018 & 10,159 \\
\hline 2019 & 10,335 \\
\hline 2020 & \\
\hline
\end{tabular}

Percentage (\%) Increase in Students Suicides Over the Years

From Report Published In Times Of India September 07, 2020

\begin{tabular}{|l|l|}
\hline Period & 1995 to 1999 \\
Suicides & 27,359 \\
Percentage increase & ----- \\
\hline Period & 2000 to 2004 \\
Suicides & 27,880 \\
Percentage increase & 2 \\
\hline Period & 2005 to 2009 \\
Suicides & 30,064 \\
Percentage increase & 8 \\
\hline Period & 2010 to 2014 \\
Suicides & 38,220 \\
Percentage Increase & 27 \\
& \\
\hline Period & 2015 to December 2019 \\
Suicides & 48,537 \\
Percentage increase & 27 \\
\hline
\end{tabular}




\section{Research Questions}

1.What are the sources of stress experienced by the competitive entrance exam aspirants attending medical and engineering coaching institutes in Delhi?

2. What are the stress coping strategies used by the competitive entrance exam aspirants attending medical and engineering coaching institutes in Delhi?

3. What are some other stress coping strategies suggested to the parents and teachers?

\section{Objectives}

1. To explore the sources of stress experienced by the competitive entrance exam aspirants attending medical and engineering coaching institutes in Delhi.

2. To assess the stress coping strategies used by the competitive entrance exam aspirants attending medical and engineering coaching institutes in Delhi.

3. To suggest some other stress coping strategies to parents and teachers.

\section{Materials and Methods}

The nature of the study was descriptive. The study was conducted in August 2019 . Cross-sectional design was used as design of the study. The population of the study comprised of students preparing for medical and engineering competitive entrance exams and attending coaching institutes in Delhi. The sample of the study was 400 students , 200 each from engineering and medical coaching institutes in Delhi and studying in $11^{\text {th }}$ and $12^{\text {th }}$ standards in schools and attended full time coaching institutes to prepare for medical and engineering entrance exams and are knowledgeable enough to answer the questionnaire.

Authorizing letter issued to the researcher for data collection by the Amity Institute of Education, Amity University, Noida ,Uttar Pradesh was produced to directors of the medical and engineering coaching institutes of Delhi. Only six coaching institutes gave their written consent for the conduct of study and data collection. The students were informed about the study and their consent was obtained along with the consent of their parents.

Self -structured questionnaire consisting of open ended questions was used as tool of the study to assess sources of stress and coping strategies used by the students preparing for medical and engineering competitive entrance exams attending coaching institutes in Delhi. The questionnaire consisted of two parts. The first part consisted of twenty open ended questions, categorised under five main headings to assess the sources of stress in the students. The second part comprised of twentytwo open ended questions to assess the coping strategies used by the medical and engineering students preparing for competitive entrance exams, to relieve stress. The face validity of the questionnaire was checked by sending it to experts. The reliability of the questionnaire was calculated using Cronbach's alpha reliability coefficient and was found to be 0.87 .

After a brief introduction of the tool, the study questionnaire was distributed to all the 400 aspirant participants. The participants were provided instructions how to answer the questions in the questionnaire. All the participants (students) were instructed to answer all the questions. The participation of the students was voluntary. The completely filled questionnaire was collected by the researcher.

\section{Statistical Analysis of Data}

Descriptive statistics was used to analyse data. The data was analysed using frequency count and percentage. Mean and Standard deviation of each item of the questionnaire for sources of stress and coping strategies was calculated.

\section{1 .Sources of stress in medical and engineering competitive entrance exam aspirants attending coaching institutes in Delhi}


Table 1 Specific Stressors of Students

\begin{tabular}{|c|c|c|c|c|c|c|}
\hline Stressor & \begin{tabular}{|l|} 
Strongly \\
not agree \\
N $(\%)$ \\
\end{tabular} & $\begin{array}{l}\text { Not } \\
\text { agreed } \\
\text { N }(\%) \\
\end{array}$ & $\begin{array}{l}\text { Agree } \\
\mathrm{N}(\%)\end{array}$ & $\begin{array}{l}\text { Strongly } \\
\text { agreed } \\
\mathbf{N}(\%) \\
\end{array}$ & Mean & $\begin{array}{l}\text { Standard } \\
\text { deviation }\end{array}$ \\
\hline \multicolumn{7}{|l|}{ Academic } \\
\hline $\begin{array}{l}\text { Lack of } \\
\text { concentration } \\
\text { in studies. }\end{array}$ & $22(5.7)$ & $47(12.3)$ & $172(45.2)$ & $139(36.5)$ & 3.12 & 1.11 \\
\hline $\begin{array}{l}\text { Too much } \\
\text { homework } \\
\text { from school }\end{array}$ & $116(30.5)$ & $112(29.4)$ & $110(28.9)$ & $40(10.5)$ & 2.18 & 1.0 \\
\hline $\begin{array}{l}\text { Low grades } \\
\text { than anticipated }\end{array}$ & $117(30.7)$ & $45(11.8)$ & $189(49.7)$ & $29(7.6)$ & 2.34 & 1.07 \\
\hline $\begin{array}{l}\text { Unnecessary } \\
\text { tension during } \\
\text { studies }\end{array}$ & $109(28.6)$ & $52(13.6)$ & $176(46.3)$ & $43(11.3)$ & 2.40 & 1.01 \\
\hline $\begin{array}{l}\text { Feel sleepy in } \\
\text { class }\end{array}$ & $50(13.1)$ & $60(15.7)$ & $170(44.7)$ & $100(26.3)$ & 2.84 & 1.01 \\
\hline \multicolumn{7}{|l|}{ Parental } \\
\hline $\begin{array}{l}\text { Lack of } \\
\text { guidance by the } \\
\text { parents }\end{array}$ & $138(36.3)$ & $103(27.1)$ & $87(22.8)$ & $52(13.6)$ & 2.13 & 1.10 \\
\hline $\begin{array}{l}\text { Pressure for } \\
\text { success and } \\
\text { high } \\
\text { expectations of } \\
\text { the parents }\end{array}$ & $51(13.4)$ & $39(10.2)$ & $190(50)$ & $100(26.3)$ & 2.89 & 1.02 \\
\hline $\begin{array}{l}\text { Lack of } \\
\text { parental } \\
\text { communication }\end{array}$ & $121(31.8)$ & $131(34.4)$ & $76(20)$ & $52(13.6)$ & 2.15 & 1.11 \\
\hline $\begin{array}{l}\text { Lack of } \\
\text { parental } \\
\text { motivation }\end{array}$ & $148(38.9)$ & $87(22.8)$ & $84(21.9)$ & 61(16) & 2.15 & 1.11 \\
\hline $\begin{array}{l}\text { Demand for } \\
\text { domestic work } \\
\text { by the parents }\end{array}$ & $193(50.7)$ & $101(26.5)$ & $73(19.2)$ & $13(3.42)$ & 1.75 & 1.08 \\
\hline \multicolumn{7}{|l|}{ Personal } \\
\hline $\begin{array}{l}\text { Change in } \\
\text { sleeping habits }\end{array}$ & $17(4.4)$ & $62(16.3)$ & $190(50)$ & $111(29.2)$ & 3.03 & 1.10 \\
\hline $\begin{array}{l}\text { Negative } \\
\text { feelings } \\
\text { towards own } \\
\text { self }\end{array}$ & $80(21)$ & $103(27.1)$ & $134(35.2)$ & $63(16.5)$ & 2.47 & 1.01 \\
\hline $\begin{array}{l}\text { High self - } \\
\text { expectations } \\
\text { regarding } \\
\text { success }\end{array}$ & $25(6.5)$ & $63(16.5)$ & $155(40.7)$ & $137(36)$ & 3.06 & 1.11 \\
\hline
\end{tabular}




\begin{tabular}{|l|l|l|l|l|l|l|}
\hline $\begin{array}{l}\text { Lack of free } \\
\text { time with } \\
\text { family and } \\
\text { friends }\end{array}$ & $109(28.6)$ & $87(22.8)$ & $136(35.7)$ & $48(12.6)$ & 2.32 & 1.07 \\
\hline $\begin{array}{l}\text { Problem in } \\
\text { staying awake }\end{array}$ & $38(10)$ & $79(20.7)$ & $189(49.7)$ & $74(19.4)$ & 2.78 & 1.03 \\
\hline Environmental & & $129(33.9)$ & $77(20.2)$ & $79(20.7)$ & $94(24.7)$ & 2.35 \\
\hline $\begin{array}{l}\text { Personal } \\
\text { problems at } \\
\text { home }\end{array}$ & $158(41.5)$ & $120(31.5)$ & $77(20.2)$ & $25(16.5)$ & 1.91 & 0.96 \\
\hline $\begin{array}{l}\text { Distractions } \\
\text { from outside } \\
\text { environment }\end{array}$ & $139(36.5)$ & $109(28.6)$ & $89(23.4)$ & $43(11.3)$ & 2.09 & 0.98 \\
\hline $\begin{array}{l}\text { Change in } \\
\text { living } \\
\text { environment }\end{array}$ & $180(47.3)$ & $122(29.4)$ & $50(13.1)$ & $39(10.2)$ & 1.86 & 0.96 \\
\hline $\begin{array}{l}\text { Divorce } \\
\text { between } \\
\text { parents }\end{array}$ & $71(18.6)$ & $99(26)$ & $188(49.4)$ & $22(15.7)$ & 2.42 & 1.01 \\
\hline $\begin{array}{l}\text { Lack of } \\
\text { vacation while } \\
\text { studies }\end{array}$ & & & & & \\
\hline
\end{tabular}

Table 1 shows various sources of stress in students .Among the academic stressors over $81.7 \%$ found lack of concentration in studies, nearly $57.3 \%$ found low grades than anticipated as source of academic stress, over $57.6 \%$ found unnecessary tension during studies .Among the parental stressors, over three quarters students $76.3 \%$ were stressed by pressure for success and high expectations of the parents. Among the personal stressors about three quarters $79.2 \%$ feel change in sleeping habits and more than half $51.7 \%$ were reported to have negative feelings towards own self. $76.7 \%$ reported problem in staying awake as cause of stress. Among the environmental stressors, 69.1 reported problem in staying awake as cause of stress. Among the environmental stressors 65.1 students reported lack of vacation while studies as major source of environmental stress. Total stressors were 20 with mean (sd ) stressor score 2.41 . 


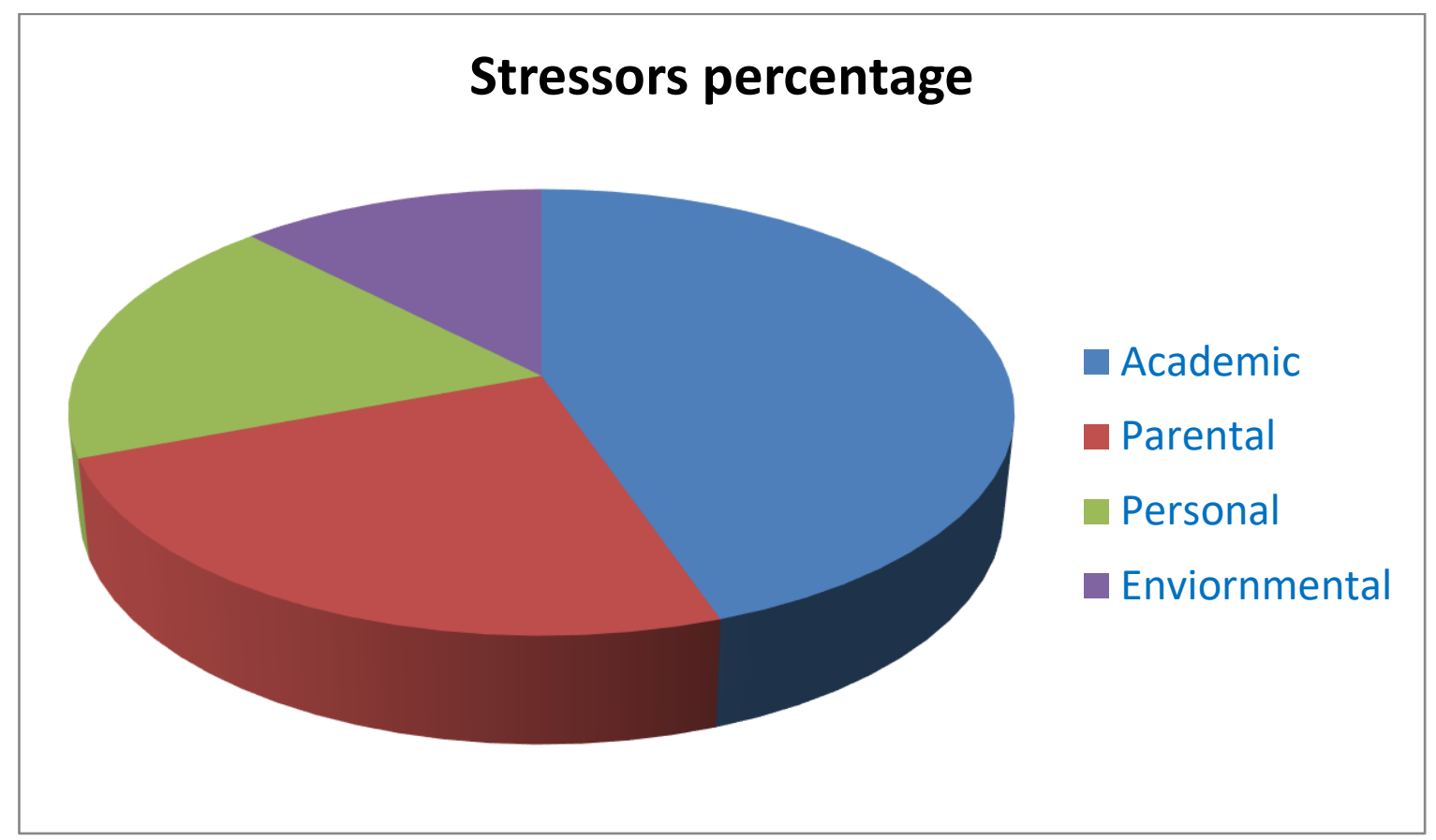

Fig 1. Major stressors in medical and engineering competitive entrance exam aspirants in Delhi

2. Stress coping strategies used by the medical and engineering competitive entrance exam aspirants attending coaching institutes

Table 2

Coping Strategies used by the students.

\begin{tabular}{|l|l|l|l|l|l|l|l|}
\hline No. & $\begin{array}{l}\text { Coping } \\
\text { strategy }\end{array}$ & $\begin{array}{l}\text { Never } \\
\mathbf{N}(\%)\end{array}$ & $\begin{array}{l}\text { Sometime } \\
\mathbf{N}(\%)\end{array}$ & $\begin{array}{l}\text { Often } \\
\mathbf{N}(\%)\end{array}$ & $\begin{array}{l}\text { Mostly } \\
\mathbf{N}(\%)\end{array}$ & Mean & $\begin{array}{l}\text { Standard } \\
\text { deviation }\end{array}$ \\
\hline 1 & $\begin{array}{l}\text { Have positive } \\
\text { thinking }\end{array}$ & $15(23.1)$ & $138(36.12)$ & $127(43.42)$ & $95(25)$ & 2.76 & 1.03 \\
\hline 2 & $\begin{array}{l}\text { Take } \\
\text { adequate } \\
\text { sleep }\end{array}$ & $13(3.4)$ & $85(22.3)$ & $141(37.1)$ & $139(36.5)$ & 3.05 & 1.10 \\
\hline 3 & $\begin{array}{l}\text { Play outdoor } \\
\text { games }\end{array}$ & $21(5.5)$ & $133(35)$ & $112(29.4)$ & $99(26)$ & 2.68 & 1.02 \\
\hline 4 & $\begin{array}{l}\text { Communicate } \\
\text { with parents }\end{array}$ & $66(17.3)$ & $141(37.1)$ & $109(28.6)$ & $52(13.6)$ & 2.32 & 1.07 \\
\hline 5 & $\begin{array}{l}\text { Talking to } \\
\text { friends }\end{array}$ & $53(13.9)$ & $100(26.3)$ & $138(36.3)$ & $89(23.4)$ & 2.69 & 1.21 \\
\hline 6 & $\begin{array}{l}\text { Offer prayers } \\
\text { in routine }\end{array}$ & $67(17.6)$ & $159(41.8)$ & $92(24.2)$ & $62(16.3)$ & 2.39 & 1.07 \\
\hline 7 & $\begin{array}{l}\text { Practice } \\
\text { yoga }\end{array}$ & $22(5.7)$ & $134(35.2)$ & $101(26.5)$ & $118(32)$ & 2.80 & 1.21 \\
\hline 8 & $\begin{array}{l}\text { Refer to } \\
\text { counsellor }\end{array}$ & $66(17.3)$ & $164(43.1)$ & $99(26)$ & $41(10.7)$ & 1.98 & 1.19 \\
\hline
\end{tabular}




\begin{tabular}{|c|c|c|c|c|c|c|c|}
\hline 9 & $\begin{array}{l}\text { Do self - } \\
\text { entertainment }\end{array}$ & $19(5)$ & $133(35)$ & $134(35.2)$ & $89(23.4)$ & 2.74 & 1.03 \\
\hline 10 & $\begin{array}{l}\text { Talking to } \\
\text { teachers }\end{array}$ & $65(17.1)$ & $164(43.1)$ & $93(24.4)$ & $48(12.6)$ & 2.27 & 1.19 \\
\hline 11 & $\begin{array}{l}\text { Organise tour } \\
\text { with family }\end{array}$ & $40(10.5)$ & $118(31)$ & $208(54.7)$ & $14(3.6)$ & 2.51 & 1.01 \\
\hline 12 & $\begin{array}{l}\text { Do } \\
\text { meditation }\end{array}$ & $30(7.1)$ & $125(32.5)$ & $99(26)$ & $119(31.3)$ & 2.77 & 1.02 \\
\hline 13 & $\begin{array}{l}\text { Playing with } \\
\text { pets }\end{array}$ & $142(37.3)$ & $149(39.2)$ & $31(8.1)$ & $58(15.2)$ & 2.01 & 0.97 \\
\hline 14 & $\begin{array}{l}\text { Time } \\
\text { management } \\
\text { for studies }\end{array}$ & $19(5)$ & $49(12.8)$ & $176(46.3)$ & $136(35.7)$ & 3.12 & 1.12 \\
\hline 15 & $\begin{array}{l}\text { Attend stress } \\
\text { management } \\
\text { course }\end{array}$ & $62(16.3)$ & $189(49.7)$ & $104(27.3)$ & $25(6.5)$ & 2.24 & 1.19 \\
\hline 16 & $\begin{array}{l}\text { Attend health } \\
\text { awareness } \\
\text { program }\end{array}$ & $146(38.4)$ & $153(40.2)$ & $42(11)$ & $39(10.2)$ & 1.93 & 1.10 \\
\hline 17 & $\begin{array}{l}\text { Visit } \\
\text { recreation } \\
\text { centre }\end{array}$ & $78(20.5)$ & $146(38.4)$ & $75(19.7)$ & $80(21)$ & 2.40 & 1.01 \\
\hline 18 & $\begin{array}{l}\text { Have breaks } \\
\text { between long } \\
\text { study hours }\end{array}$ & $36(9)$ & $25(6.5)$ & $161(42.3)$ & $158(41.5)$ & 3.16 & 1.13 \\
\hline 19 & $\begin{array}{l}\text { Listen } \\
\text { music }\end{array}$ & $73(19.3)$ & $117(30.7)$ & $109(28.6)$ & $81(21.3)$ & 2.52 & 1.01 \\
\hline 20 & $\begin{array}{c}\text { Interact on } \\
\text { social media }\end{array}$ & $23(6)$ & $56(14.7)$ & $208(54.7)$ & $93(24.4)$ & 2.97 & 1.05 \\
\hline 21 & $\begin{array}{l}\text { Play } \\
\text { computer } \\
\text { games } \\
\end{array}$ & $164(43.1)$ & $41(10.7)$ & $149(39.2)$ & $21(5.5)$ & 2.04 & 1.01 \\
\hline 22 & $\begin{array}{l}\text { Go } \\
\text { shopping }\end{array}$ & $167(43.9)$ & $123(32.3)$ & $41(10.7)$ & $48(12.6)$ & 1.91 & 1.22 \\
\hline
\end{tabular}

Majority of the students [380(95\%] often followed stress coping strategies that would make them feel happy and relaxed when they felt stress. The various measures adopted by students to deal with stress were interact on social media $54.7 \%$, taking adequate sleep $73.6 \%$, talking with friends $59.7 \%$
, practice meditation $57.3 \%$, performing yoga $59.6 \%$, managing full time for studies $82 \%$, listen to music $49.9 \%$. Other methods like play computer games, have break between long study hours, do self- entertainment were also reported by students. 


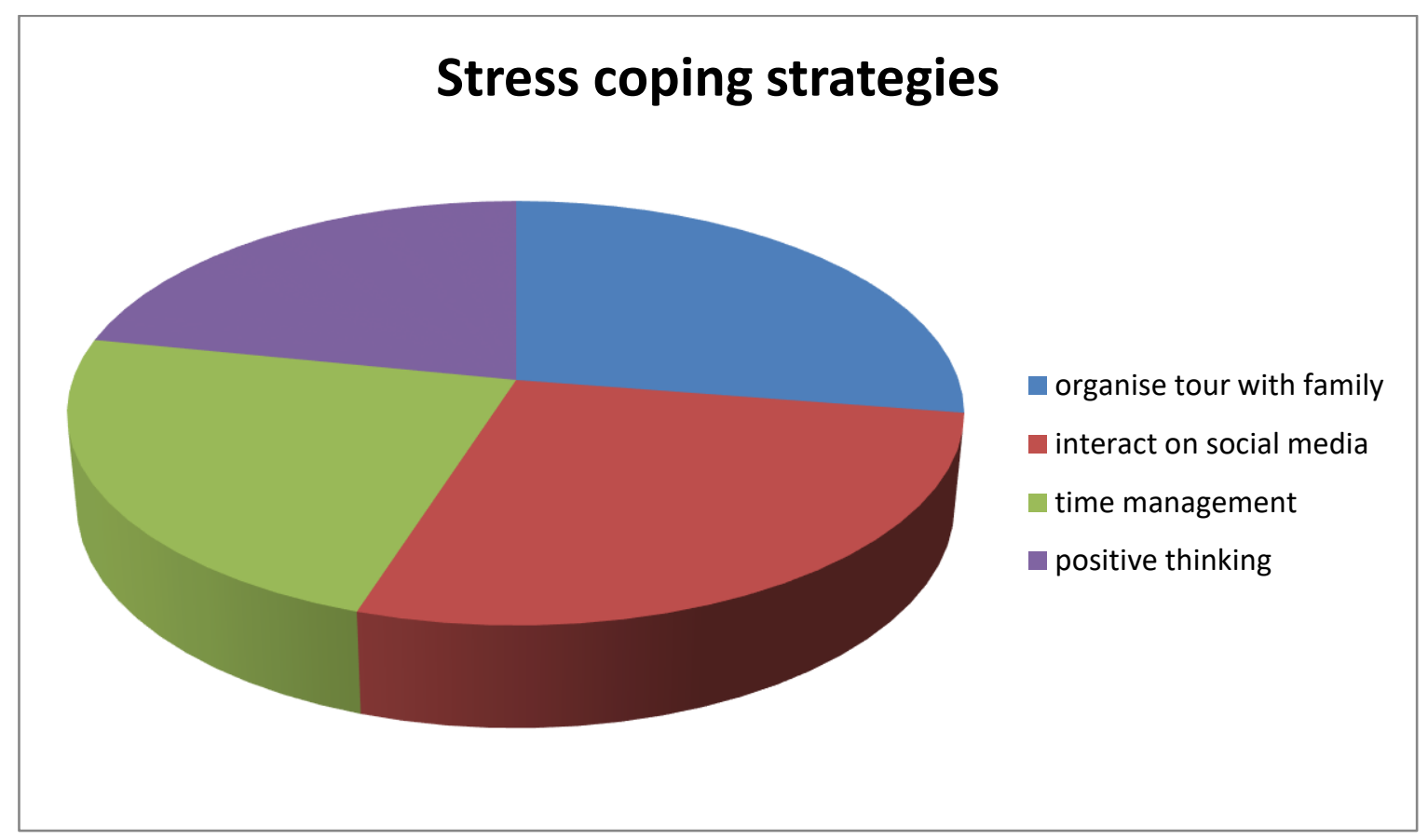

Fig 2. Major stress coping strategies

\section{Major Findings and Discussions}

The study was carried out to explore the sources of stress and to assess the stress coping strategies employed by the medical and engineering competitive entrance exam aspirants attending coaching institutes in Delhi A number of 380 (95\%) students participated in this study .The prevalence of stress due to its sources was high. In this study major sources of stress were academic and parental. Students also reported being affected by personal and environmental sources. Academic stressors contributed $81.7 \%$, as the source of stress. While among the parental stressors $76.3 \%$ students were stressed by pressure for success and high expectations of the parent. Among the personal stressors $79.2 \%$ felt change in sleeping habits as stressor . Environmental factors also influenced the preparation of the medical and engineering students . Majority of the students used stress coping strategies such as listening to music $49.9 \%$ , practice yoga $59.6 \%$, and meditation $57.3 \%$, talking to friends $59.7 \%$, interacting social media $54.7 \%$, take adequate sleep $73.6 \%$ and managing time for studies.The mean score and standard deviation of each item of academic, parental ,personal and environmental stressors was calculated. Similarly the mean score and standard deviation of each item of stress coping strategies was calculated. Other students also used strategies like organising tours with family, playing outdoor games, visit to recreation centre, getting guidance and counselling services in order to relieve stress. The findings of the study will be beneficial to teachers, parents and students themselves.The findings will also be useful to the students preparing for other competitive entrance exams. The study will serve as a base to further researchers.

\section{Conclusion}

It is clear from the findings of this study that the students preparing for competitive entrance exams , who have joined coaching institutes for admission to medical and engineering professional courses experience academic ,parental, personal and environmental stress. The highly competitive education, high pressure for success and parental expectations for success in competitive entrance exams are affecting student's state of mind, which results in lack of concentration, negative feelings towards own -self and lack of sleep among majority of students. Students also feel academically stressed when they get low grades than anticipated in their practice tests. Three quarter students feel very high pressure for success and high expectations from parents as source of 
their stress and thus study for long hours .Majority(two -third ) of the students feel change in sleeping habits, while some reported negative feelings towards own -self and problem in staying awake as personal source of stress. A majority of students reported lack of free time and vacation as environmental source of stress. These stressors affect the students by affecting their physical, emotional, social ,sleep and behavioural aspects of life . Stress coping involves complete change in lifestyle of students that requires various strategies and techniques. They include taking adequate sleep, communicating with parents, talking with like- minded people, practising yoga and meditation, managing time for studies, listening music, interacting social media. These allow the adolescents to reduce and cope with negative feelings and help in recognition of situations that lead to negative emotions. Majority of the students often follow stress coping strategies. About threequarter of participants follow time management for their studies. More than half of the aspirants take adequate sleep to cope with stress, majority of the students talk with like- minded people to relieve their stress. Others practise yoga and perform meditation as coping strategies. A few participants manage their stress by using strategies like playing computer games, do self- entertainment and have breaks between long study hours. It is evident from the study that most of the students practice one or the other stress coping strategies to relieve stress. It is also essential that both parents and teachers should understand their children and help them in relieving stress and should not become the contributor factors. The students must adopt stress coping strategies on a routine basis and if one strategy does not work then other strategy should be applied to relieve stress

\section{Financial Disclosure/ Conflict of Interest}

The author declare that there was no financial aid received and no conflict of interest associated with this research work.

\section{References}

[1]. Reddy JK., Menon KR ., Thattil A., Academic Stress and its Sources Among University Students . Biomedical and
Pharmacogoloy journal. Available from : http://DX.doi.org/10.13005/bpj/1404

[2]. Pascoe CM., Hetrick ., ES ., Parke GA.,The Impact of Stress on Students in Secondary School and Higher Education . International Journal of Adolescent and Youth . Volume 25 ,2020. Available from https://doi;org/10./080/267384.2011.15 96823.

[3]. Deb S, Strodi E, Sun J., Academic Stress , Parental Pressure , Anxiety and Mental Health among Indian High School Students . Available from : DOI:10.5923/j.ipbs.20150501.04

[4]. Prerna Sindwani., Fear self - loathing and stress affect students appearing for competitive exams : UNESCO Study 2017 .Available from : https://www.businessinsider.in

[5]. Sethumadhvan PT., Article , Coaching causes stress among students preparing for entrance exams: UNESCO Study November 2017. Available from: https://english.mathrubhumi.com

[6]. Prajapati N., Singh Dr K., Sources of Stress among Students Preparing in Various Competitive Exams for Job . Available from www.ijcrt.org@2017IJCRT/Volume5,I ssue4,December2017ISSN2320-2882

[7]. 1 Shrivastana. DrA.,Rajan Dr.D.,Assessment of Depression ,Anxiety and Stress among Students Preparing for Various Competitive Exams. Available from : www.researchpublish.com,Volume6, Iss ue1,pp:(50-72)

[8]. Adler,N.,\& Park,C.(2003)Coping Styles as a Predictor of Health and Well Being across the First year Medical School. Journal of Health Psychology ,22(6), 187-189

[9]. Olo1*., Impact of Spirituality on Depression, Anxiety and Stress of Students Preparing For Competitive Exams. Volume 3, Issue 3,No.11,DIP :18.01.193/20160303. Available from : http://www.ijipm.M,April-June16 
[10]. Prabhu Dr.SP., A Study on Academic Stress among Higher Secondary Students.Volume-4, Issue 10/,2015//pp.63-68.Available from: www.ijhssi.org

[11]. Archana Kumari., Examination ,Stress and Anxiety : A Study of College Students. Article, December 2014.Available from : https://www.researchgate.,JagritiJannet/ publication/27185210

[12]. Joseph N.,Nallapati A., Machado XM., Nair V., Matrle S., Muthuswamy N., \& Sinha A., Assessment of academic stress and its coping mechanism among medical undergraduate students in a large Midwestern University .Springer Link.Available
from:https://link.springer.com.Publishe d: 27July 2020,Current Psychology

[13]. Samira S.Bamahair, 1 Ali I .Al Farhan ,2 Alaa. Althubaiti,3 Sajioda Agha,4 Saeed ur Rahman ,2 and Nadia O .Ibrahim1. Sources of Stress and Coping Strategies among Undergraduate Medical Students Enrolled in a Problem - Based Learning Curriculum . Journal of Biomedical Education/2015/Article Volume 2015. Available from: https://doi/org/10.1155/2015/575139

[14]. How to cope with stress,. Times of India.com,Jan24, 2020

[15]. Examination Stress : Its Causes and how to deal with it . Article, Available from : https://www.embibe.com

[16]. Reports of National Crime Records Bureau www.ncrb.gov.in

\section{APPENDIX -1}

\section{The Sources of Stress Questionnaire for Medical and Engineering Competitive Exams Aspirants}

Instructions:-

This scale is designed to know the frequency of occurrence of the sources of stress. Kindly read each statement in the following scale carefully and indicate the response by placing a tick mark in the appropriate column. The information provided by you will be kept confidential and will be used only for the study purpose.

\begin{tabular}{|l|l|l|l|l|}
\hline Stressor & $\begin{array}{l}\text { Strongly not } \\
\text { Agree N (\%) }\end{array}$ & $\begin{array}{l}\text { Not Agreed } \\
\text { N (\%) }\end{array}$ & $\begin{array}{l}\text { Agree } \\
\text { N (\%) }\end{array}$ & $\begin{array}{l}\text { Strongly } \\
\text { Agreed } \\
\text { N (\%) }\end{array}$ \\
\hline ACADEMIC & & & & \\
\hline $\begin{array}{l}\text { Lack of concentration } \\
\text { in studies }\end{array}$ & & & & \\
\hline $\begin{array}{l}\text { Too much homework } \\
\text { from school }\end{array}$ & $\begin{array}{l}\text { Low grades than } \\
\text { anticipated }\end{array}$ & & & \\
\hline Feel sleepy in class & & & & \\
\hline PARENTAL & & & & \\
\hline $\begin{array}{l}\text { Lack of guidance by } \\
\text { the parents }\end{array}$ & & & & \\
\hline
\end{tabular}




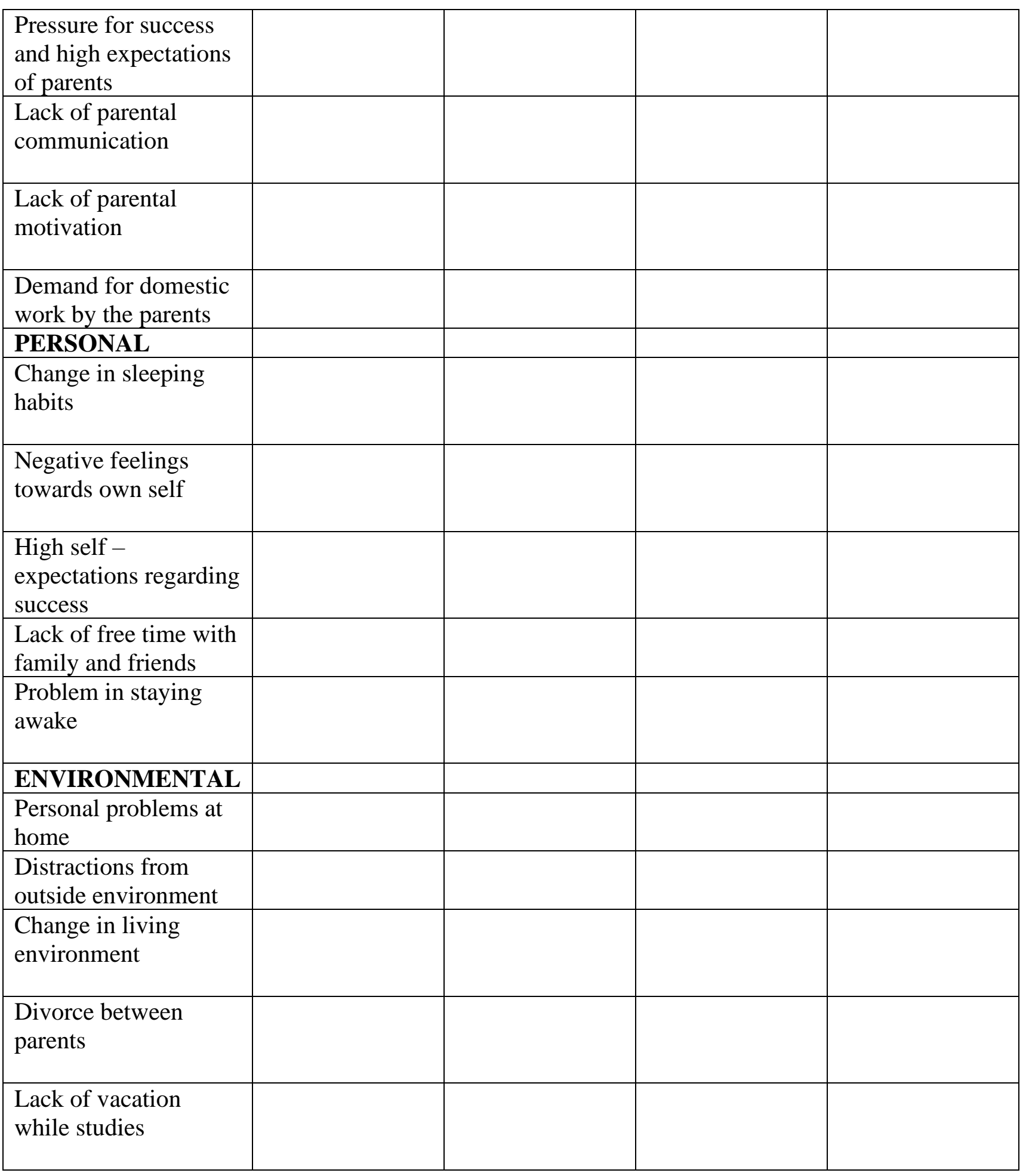

\section{APPENDIX-2}

The Coping Strategy Questionnaire for Medical and Engineering Competitive Entrance Exams Aspirants

\begin{tabular}{|l|l|l|l|l|l|}
\hline S. No & Coping & Never & Sometime & Often & Mostly \\
& Strategies & N $(\%)$ & N $(\%)$ & N $(\%)$ & N $(\%)$ \\
\hline
\end{tabular}




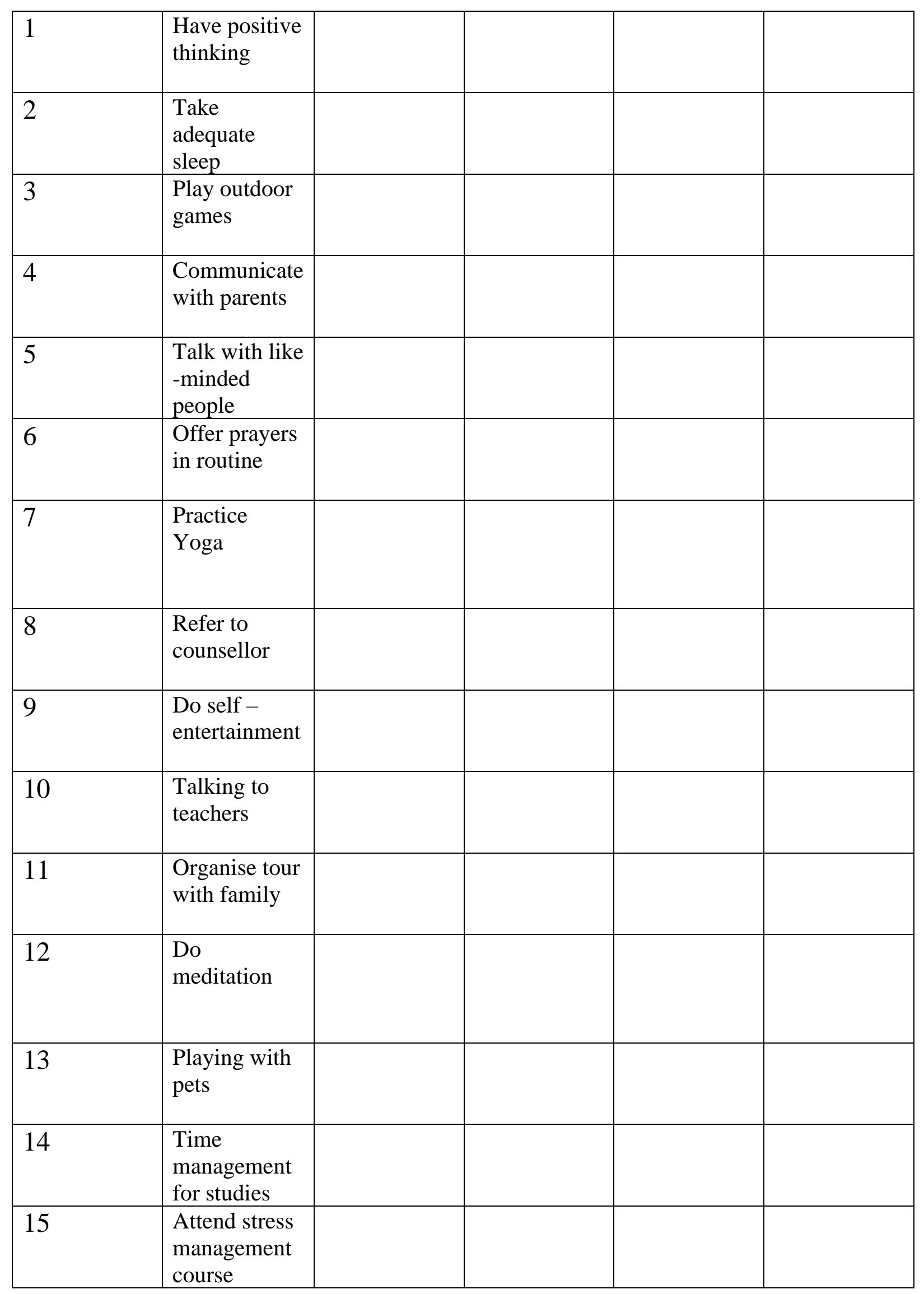




\begin{tabular}{|l|l|l|l|l|l|}
\hline 16 & $\begin{array}{l}\text { Attend health } \\
\text { awareness } \\
\text { program }\end{array}$ & & & & \\
\hline 17 & $\begin{array}{l}\text { Visit } \\
\text { recreation } \\
\text { centre }\end{array}$ & & & & \\
\hline 18 & $\begin{array}{l}\text { Have breaks } \\
\text { between long } \\
\text { study hours }\end{array}$ & & & & \\
\hline 19 & $\begin{array}{l}\text { Listen music } \\
\text { Social media }\end{array}$ & & & & \\
\hline 21 & $\begin{array}{l}\text { Interact on } \\
\text { computer } \\
\text { games }\end{array}$ & & & & \\
\hline 22 & \begin{tabular}{l} 
Go shopping \\
\hline
\end{tabular} & & & & \\
\hline
\end{tabular}

Frequency count of the number of responses against each option was calculated and percentage analysis was done. 